\title{
EKG 7-2014: Trigeminismo de la Unión.
}
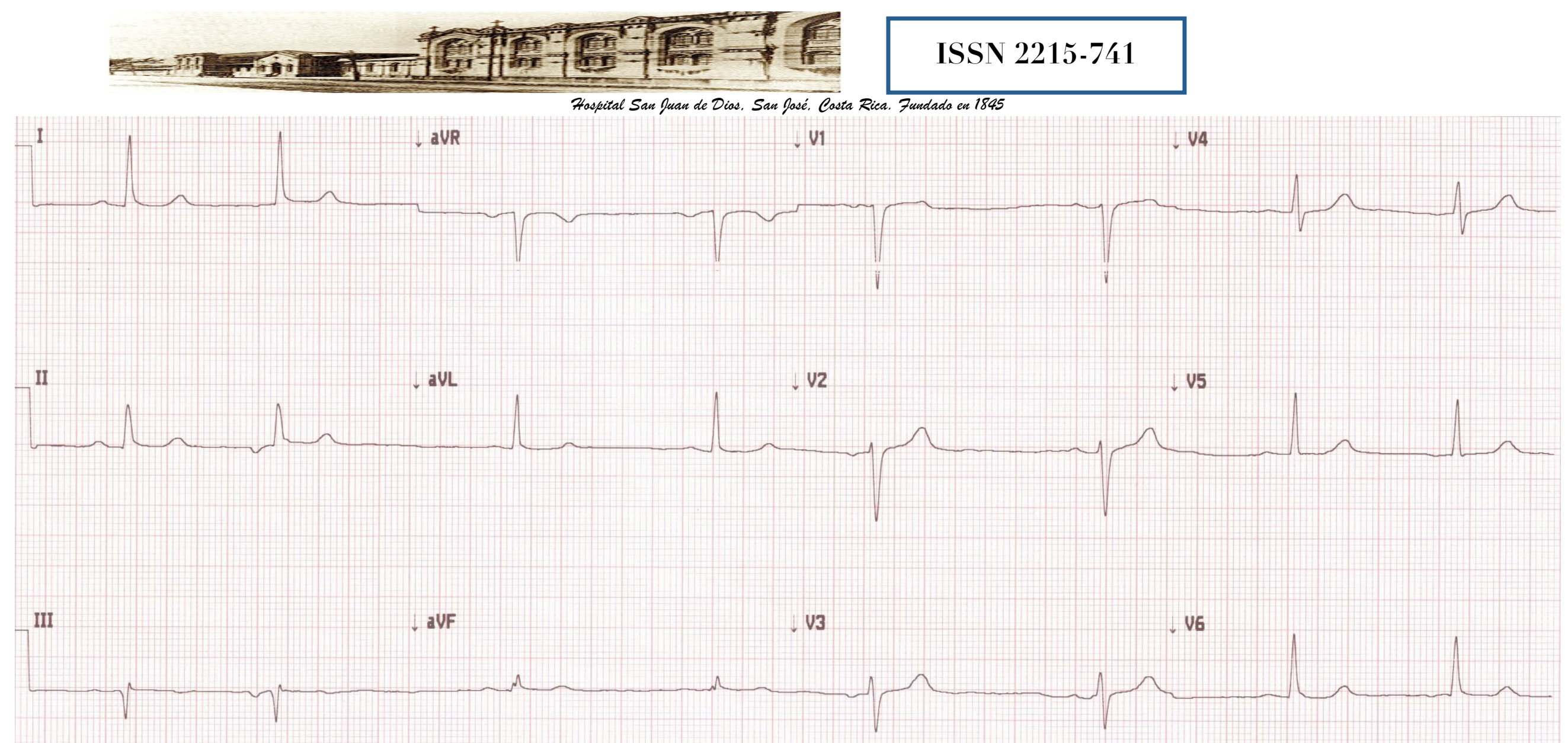

II 